\title{
Survei Penentuan dan Pengontrolan Batas Zona Penyusun Main Dam pada Proyek Bendungan Ladongi Provinsi Sulawesi Tenggara
}

\section{Survey on Determination and Controlling of the Main Dam Zones in Shoutheast Sulawesi Ladongi Dam Project}

\author{
Afifah Aprilianda1, Muhammad Zainuddin Lubis², Agung Permana ${ }^{3}$, Sidik Dwi Pamungkas ${ }^{4}$, Muhammad Adam ${ }^{5}$ \\ 1 Mahasiswa Program Studi Teknik Geomatika, Politeknik Negeri Batam, Batam 29461, Indonesia \\ 2 Dosen Program Studi Teknik Geomatika, Politeknik Negeri Batam, Batam 29461, Indonesia \\ 3 PPK Bendungan I, Satker Pembangunan Bendungan BWS Sulawesi IV, Kendari 93115, Indonesia \\ ${ }^{4}$ Geodetic Engineer, Kontraktor Pelaksana Proyek Bendungan Ladongi, Kolaka Timur 93573, Indonesia \\ 5 Inspektor Konsultan, Konsultan Supervisi Proyek Bendungan Ladongi, Kolaka Timur 93573, Indonesia
}

Penulis Korespondensi: Afifah Aprilianda | Email: afifahaprilianda@gmail.com

Diterima (Received): 18/08/2020 Direvisi (Revised): 26/10/2020 Diterima untuk Publikasi (Accepted): 27/10/2020

\begin{abstract}
ABSTRAK
Ada banyak manfaat yang dapat dinikmati masyarakat sekitar pembangunan bendungan seperti persedian air, pembangkit listrik, irigasi dan tempat rekreasi. Karena mempunyai banyak manfaat dalam hal ini pemerintah melakukan program Percepatan Pelaksanaan Proyek Strategis Nasional. Salah satu bendungan yang dibangun yaitu Bendungan Ladongi yang terletak di Provinsi Sulawesi Tenggara. Bendungan Ladongi dengan tipe urugan batu inti tegak (bendungan yang terdiri dari batuan dengan dengan gradasi yang berbeda-beda dalam urutan perlapisannya) mempunyai salah satu bagian yaitu tubuh bendungan utama (main dam) yang berfungsi sebagai penyangga penahan air dari arah hulu ke hilir sungai. Dalam hal ini diperlukan peran survey sebagai penentuan dan pengontrolan batas zona penyusun main dam agar dapat menahan rembesan air serta pembangunannya sesuai dengan desain perencanaannya. Dengan mengunakan metode stake out, pengukuran situasi, galian dan timbunan, hasil yang diperoleh pada penelitian ini berupa Peta Topografi Main Dam, Cross Section Main Dam dan visualisasi tiga dimensinya dari Opnam 5 sampai dengan Opnam 9. Elevasi pada Opnam 5 adalah $+60.00 \mathrm{~m}$ sampai dengan $+65.29 \mathrm{~m}$ dengan volume timbunan sebesar 11,965 $\mathrm{m}^{3}$. Pada Opnam 6 memiliki elevasi dari $+60.07 \mathrm{~m}$ sampai $+68.22 \mathrm{~m}$ dengan volume sebesar $29,701 \mathrm{~m}^{3}$. Elevasi Opnam 7 berkisar pada $+65.01 \mathrm{~m}$ sampai $+70.80 \mathrm{~m}$ dengan $43,057 \mathrm{~m}^{3}$. Opnam 8 memiliki elevasi dari $+72.31 \mathrm{~m}$ sampai $+80.25 \mathrm{~m}$ dengan volume timbunan $79,107 \mathrm{~m}^{3}$. Dan elevasi pada Opnam berkisar dari $+63.18 \mathrm{~m}$ sampai $+86.10 \mathrm{~m}$ dengan volume timbunan sebesar $99,378 \mathrm{~m}^{3}$.
\end{abstract}

Kata Kunci: main dam, zona penyusun main dam, peta topografi, cross section, cut and fill.

\begin{abstract}
Many benefits can be enjoyed by the community around the construction of the dam, such as water supplies, power plants, irrigation, and recreation areas. Because it has many benefits, in this case, the government is implementing the Accelerated Implementation of the National Strategic Projects program. One of the dams built is the Ladongi Dam, located in Southeast Sulawesi Province. The Ladongi dam with an upright core rockfill type (a dam consisting of rocks with different gradations in the order of its layers) has one part, namely the main dam which functions as water retaining buffer from upstream to downstream of the river. In this case, the role of the survey is needed as the determination and control of the boundary of the main dam's constituent zone so that it can withstand water seepage and its construction following the planning design. By using the stakeout method, situation measurement, excavation, and stockpiling, the results obtained in this study are the Main Dam Topographic Map, Main Dam Cross Section, and three-dimensional visualization from Opnam 5 to Opnam 9. The elevation in Opnam 5 is $+60.00 \mathrm{~m}$ to with $+65.29 \mathrm{~m}$. Opnam 6 has an elevation from $+60.07 \mathrm{~m}$ to $+68.22 \mathrm{~m}$. Opnam 7 elevation ranges from $+65.01 \mathrm{~m}$ to $+70.80 \mathrm{~m}$. Opnam 8 has an elevation from $+72.31 \mathrm{~m}$ to $+80.25 \mathrm{~m}$. And the elevation at Opnam ranges from $+63.18 m$ to $+86.10 m$.
\end{abstract}

Keywords: main dam, main dam building zone, topographic map, cross section, cut and fill method.

(C) Author(s) 2020. This is an open access article under the Creative Commons Attribution-ShareAlike 4.0 International License (CC BY-SA 4.0). 


\section{Pendahuluan}

Pembangunan bendungan akan membawa dampak positif dan mempunyai banyak manfaat yang dapat dinikmati masyarakat sekitar seperti adanya persediaan air, pembangkit listrik dan tempat rekreasi (Dharmayasa, dkk., 2014). Di dalam Peraturan Pemerintah Republik Indonesia Nomor 37 Tahun 2010 mengatakan bendungan adalah bangunan yang berupa urukan tanah, urukan batu, beton, dan /atau pasangan batu yang dibangun untuk menahan dan menampung limbah tambang (tailing) atau menampung lumpur sehingga terbentuk waduk.

Karena mempunyai banyak manfaat dari pembangunan bendungan, menurut Peraturan Presiden Republik Indonesia Nomor 3 Tahun 2016 pemerintah melakukan program Percepatan Proyek Strategis Nasional atau yang disingkat PSN. Salah satu bendungan yang dibangun dari program tersebut yaitu Bendungan Ladongi terletak di Provinsi Sulawesi Tenggara.

Bendungan memiliki banyak tipe salah satunya adalah tipe bendungan urugan. Bendungan urugan adalah bendungan yang dibangun dari hasil penggalian bahan (material) tanpa bahan tambahan lain yang bersifat campuran secara kimia, sehingga merupakan bahan pembentuk bendungan asli (Soedibyo, 2003). Dalam pengelompokan tipe bendungan berdasarkan material pembentuknya maka yang paling lazim digunakan dalam diskusi desain yaitu bendungan urugan tanah dan bendungan urugan batu. Dan secara garis besar bendungan urugan dapat digolongkan menjadi dua tipe yaitu homogen dan berzona (dengan inti tegak atau inti miring). Pembuatan zona-zona pada tubuh bendungan (main dam) bertujuan meningkatkan keamanan bendungan yaitu untuk mendapatkan kekuatan (strength) yang cukup (Balai Keamanan Bendungan, dkk., 2003).

Secara umum bendungan memiliki bagian paling inti yaitu main dam atau tubuh bendungan yang berfungsi sebagai peninggi muka air. Sehubungan dengan fungsinya, metode pelaksanaan penimbunan material bendungan harus tepat agar main dam mampu menahan rembesan air sungai (Nasmiarta, dkk., 2016). Pada pelaksanaan konstruksi tubuh bendungan ada beberapa tahapan yang dilakukan yaitu pembangunan bendungan pengelak (primary cofferdam), anak bendungan (main cofferdam) dan tubuh bendungan utama (main dam) (Asiyanto, 2011).

Pada pembangunan Bendungan Ladongi menggunakan tipe bendungan urugan batu berzona dengan inti tegak (bendungan yang terdiri dari batuan dengan gradasi yang berbeda-beda pada ururtan perlapisannya). (PT Wecon, 2016). Dalam hal ini diperlukan peran survey pada penentuan dan pengontrolan batas zona timbunan agar main dam sesuai dengan desain perencanaannya dan meminimalisir rembesan air dari hulu ke arah hilir sungai.

Dari latar belakang tersebut maka penulis membuat penelitian ini berdasarkan pentingnya mengkaji tentang survey penentuan dan pengontrolan batas zona penyusun main dam. Melalui pengukuran stake out dan pemetaan situasi yang selanjutnya data hasil pengukuran diolah untuk mendapatkan Peta Topografi Main Dam, kenampakan profil melintang main dam menggunakan software AutoCad Civil 2017 serta didapatkan data dari metode cut and fill yaitu berupa volume timbunan main dam dan visualisasi tiga dimensinya menggunakan software Surfer 9.

\section{Data dan Metodologi}

\subsection{Data dan Lokas}

Lokasi yang digunakan untuk penelitian ini adalah area main dam pada Bendungan Ladongi yang terletak di Kecamatan Ladongi, Kabupaten Kolaka Timur, Provinsi Sulawesi Tenggara. Dengan letak geografis berada pada koordinat $4^{\circ} 08^{\prime} 52^{\prime \prime}$ - $4^{\circ} 08^{\prime} 53^{\prime \prime}$ LS dan $121^{\circ} 52^{\prime} 43^{\prime \prime}-$ $121^{\circ} 53^{\prime} 34^{\prime \prime} \mathrm{BT}$.

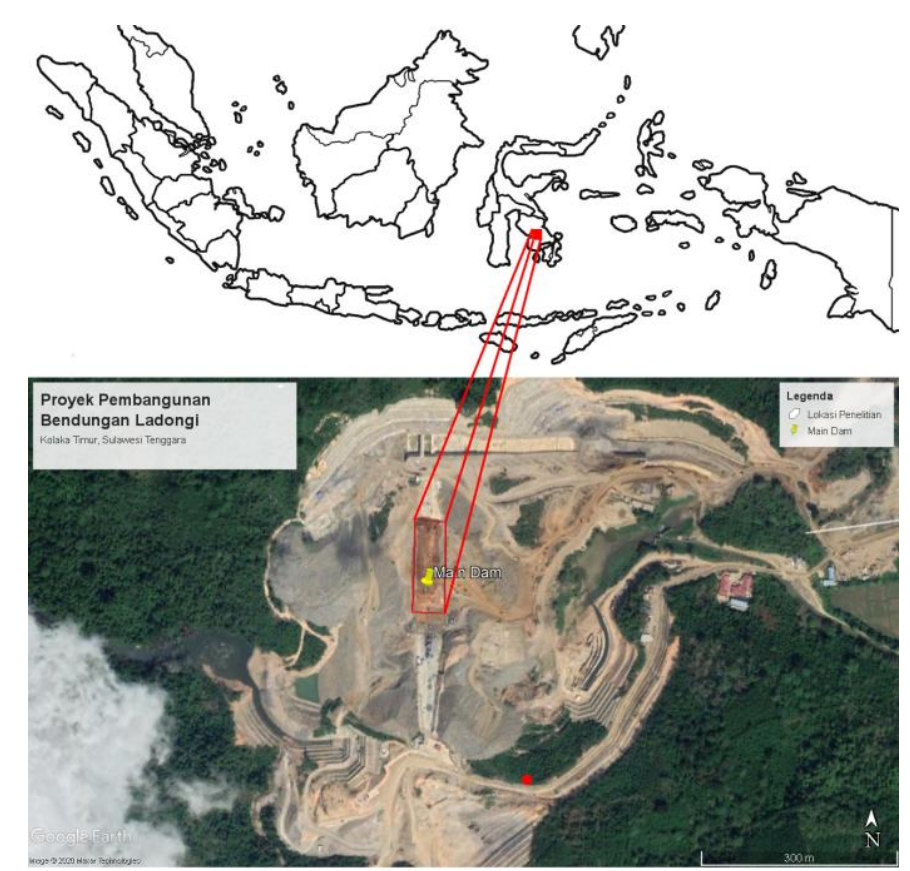

Gambar 2.1. Lokasi Penelitian

Data-data yang digunakan dalam penelitian ini adalah data primer dan data sekunder yang didapat dari instansi terkait. Data Primer yaitu hasil dari pengambilan data di lapangan melalui observasi lapangan dan pengukuran. Sedangkan data sekunder merupakan data yang didapatkan melalui Kantor Konsultan Supervisi Bendungan Ladongi PT. Bintama Wirawredha - PT. Arga Pasca Rencana, KSO dan Kantor Kontraktor Bendungan Ladongi PT. Hutama Karya - Bumi Karsa, KSO.

\subsection{Metodolog}

Pelaksanaan timbunan main dam dilakukan dengan metode penimbunan berlapis-lapis (stratifying method) yaitu dengan menempatkan material pada tempat tertentu, kemudian diratakan hingga mencapai ketebalan yang efektif untuk pemadatan (Suyono dan Takeda, 1977). Proses pengukuran dalam penentuan dan pengontrolan batas zona penyusun main dam dapat dijelaskan sebagai berikut. 


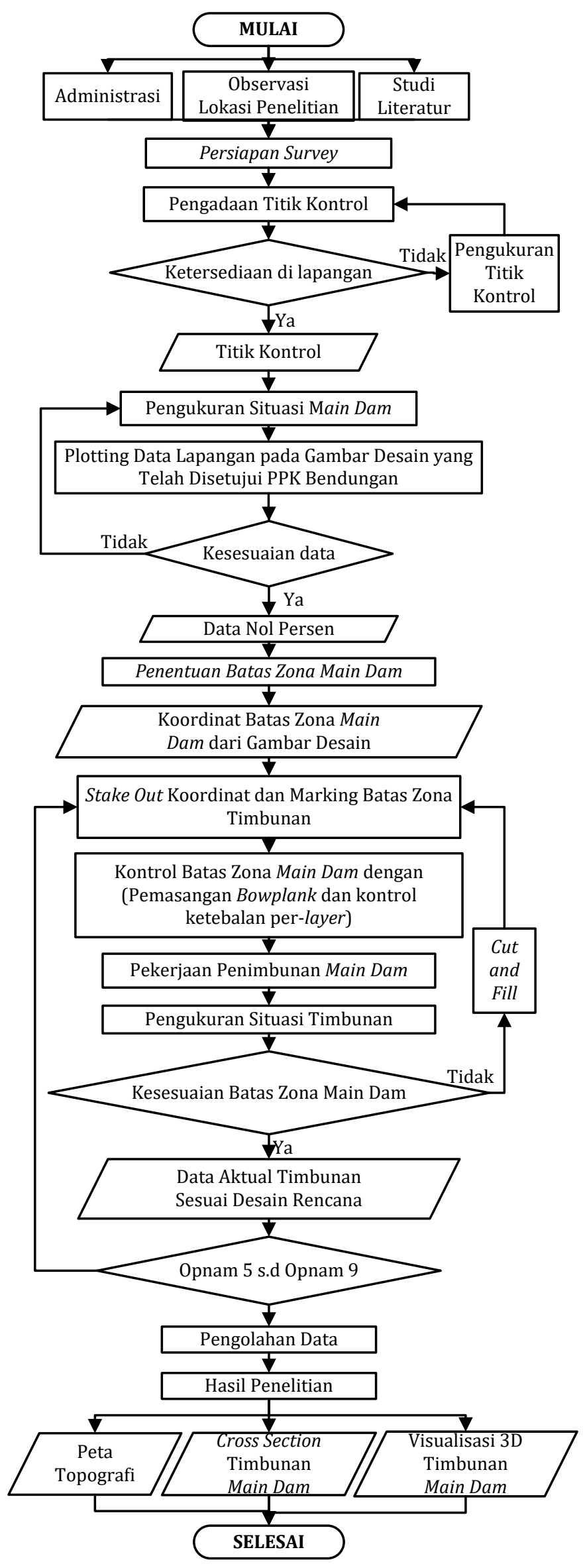

Gambar 2.2. Diagram Alir Penelitian

\subsection{Alat dan Bahan}

Alat yang digunakan dalam penelitian ini sebagai berikut:

1. Total Station merk SOKKIA (CX-101). Serial No. GP1923.

2. Prisma Detail dan Monopole merk SOKKIA.

3. Statif / Tripod merk SOKKIA PFA-1.

4. Meteran merk TEKIRO 5M.

5. Laptop merk ACER - Aspire F5-573G Intel® Core $^{\mathrm{TM}}$ i5-6200U CPU @ 2.30GHz 2.40 GHz, RAM 8.00 GB.

6. Software AutoCAD Civil 3D 2017 dan Surfer9

Adapun bahan yang digunakan dalam penelitian ini sebagai berikut:

1. Data Shop Drawing Main Dam Bendungan Ladongi. Data ini berupa gambar rencana keseluruhan bendungan yang digunakan sebagai referensi dalam mengaplikasikan rencana kerja di lapangan.

2. Data Shop Drawing Cross Section Main Dam Bendungan Ladongi. Data ini berupa gambar profil melintang rencana pada main dam yang dibagi setiap STA (stasiun) 20 meter.

3. Data Teknis Main Dam Bendungan Ladongi. Data ini berupa informasi tentang seluruh acuan pekerjaan pembangunan Bendungan Ladongi.

4. Data Bench Mark (BM) dan Control Point (CP) Bendungan Ladongi. Data ini berupa informasi koordinat dan elevasi yang digunakan sebagai titik acuan pekerjaan dilapangan.

5. Data detail situasi timbunan main dam (opnam 5 sampai dengan opnam 9). Data pengukuran ini terdiri dari data shop drawing yang sudah digabungkan dengan hasil pengukuran di lapangan.

\subsection{Zona Penyusun Main Dam}

Dibandingkan dengan tipe lain, bendungan dengan tipe urugan merupakan bendungan yang paliing lazim dibangun karena konstruksinya menggunakan material galian setempat yang tersedia dan tidak memerlukan banyak pemroresan.

Bendungan urugan dapat dibangun hampir pada segala jenis tanah pondasi maupun bentuk topografi yang kurang baik dan umumnya lebih sering dibangun dengan tujuan penampung air (Balai Keamanan Bendungan, dkk., 2003).

Menurut (Proyek Bendungan Ladongi, 2019) mengatakan bendungan urugan yang berzona memiliki timbunan yang dilaksanakan sesuai dengan garis, angka dan dimensi seperti yang ditunjukkan pada gambar rencana. Pembagian garis antara zona-zona timbunan tergantung dari zona masing-masing, yaitu:

Tabel 2.1. Zona Penyusun Main Dam

\begin{tabular}{lcc}
\hline \multicolumn{1}{c}{ Zona } & Warna & Keterangan \\
\hline Zona 1 & Cokelat & Tanah Kedap Air (Inti) \\
Zona 2A & Kuning & Filter Halus \\
Zona 2B & Merah & Filter Kasar \\
Zona 3 & Hijau & Timbunan Batu \\
Zona 4 & Biru & Batu Rip-Rap \\
Main & Hitam & Anak Bendungan \\
Cofferdam & & \\
\hline
\end{tabular}




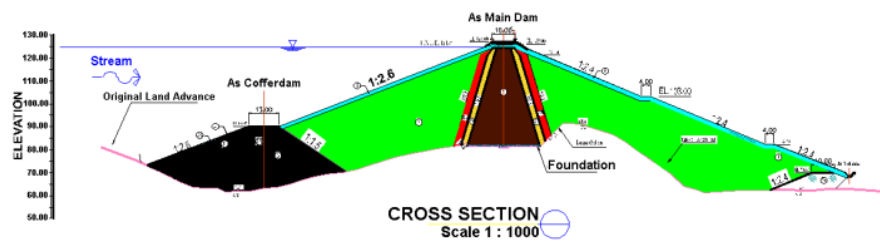

Gambar 2.3. Cross Section Zona Penyusun Main Dam

Penempatan dan perataan material dilakukan secara kontinu, horizontal, lapis demi lapis dengan tebal tiap lapis maksimum $30 \mathrm{~cm}$ setelah dipadatkan. Pembentukan kemiringan bagian tepi timbunan harus dilakukan sesuai gambar atau seperti ditunjukkan direksi (Proyek Bendungan Ladongi, 2019).

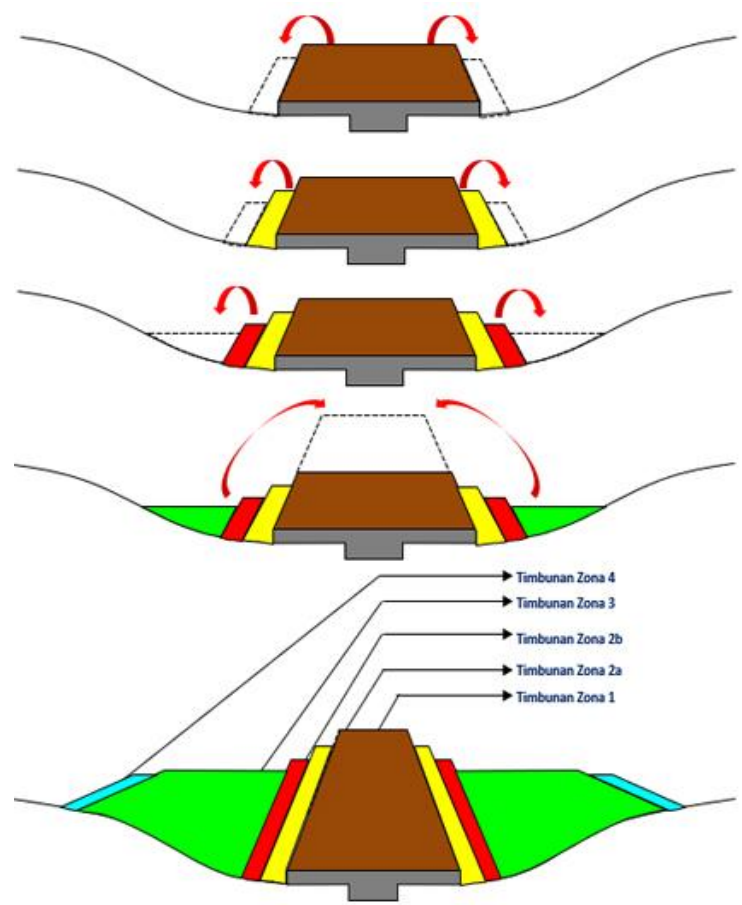

Gambar 2.4. Tahapan Penimbunan Material Bendungan

\subsection{Survey Topografi}

Survey bertujuan untuk mengamati keadaan disuatu area yang di dalamnya meliputi pengumpulan data (terdiri dari arah, jarak dan data ketinggian) pada area tersebut menggunakan metode (teknik) tertentu. Pengukuran topografi umumnya dilakukan dengan tiga metode popular yaitu metode terestris, metode fotogrametri dan metode remote sensing. Metode terestris digunakan untuk menghasilkan peta topografi skala besar dan metode ini merupakan yang paling umum diselenggarakan secara langsung di lapangan (Sobatnu, 2018).

Untuk melakukan pengukuran dilapangan menggunakan total station yaitu alat ukur sudut dan jarak yang terintegrasi dalam satu unit alat yang sudah dilengkapi dengan processor sehingga bisa menghitung jarak dataran koordinat dan beda tinggi secara langsung (Adi dan Aghastya, 2017). Dengan menggunakan metode Tachymetri sangat bermanfaat dalam penentuan lokasi sejumlah besar detail topografi, baik horizontal maupun vertikal dengan transit atau planset. Di wilayah-wilayah perkotaan, pembacaan sudut dan jarak dapat dikerjakan lebih efisien dan cepat daripada pencatatan pengukuran dan pembuatan sketsa oleh pencatat (Purwaamijaya, 2008).

Dalam pelaksanaan pengukuran di lapangan ada tahapan persiapan yang harus diperhatikan seperti penyediaan gambar kerja (shop drawing) serta mobilisasi peralatan survey. Dan beberapa hal lainnya yang harus diperhatikan yaitu:

- Titik Kontrol, dijadikan sebagai referensi/acuan dalam pengukuran di lapangan. Bench mark (BM) adalah monument/tugu/patok beton yang telah diketahui koordinatnya dan elevasinya $(\mathrm{x}, \mathrm{y}, \mathrm{z})$ (Sobatnu, 2018). Pada pengukuran penentuan dan pengontrolan batas zona penyusun main dam menggunakan 2 titik kontrol yaitu BM 8 dan CP 8 yang berada di gardu pandang Proyek Bendungan Ladongi. Titik kontrol tersebut digunakan untuk pengukuran detail situasi di lapangan sebagai titik referensi untuk membuat titik bantu.

Tabel 2.2. Titik Kontrol Proyek Bendungan Ladongi

\begin{tabular}{|c|c|c|c|c|}
\hline \multirow[b]{2}{*}{ No } & \multirow{2}{*}{ Nama } & \multicolumn{3}{|c|}{ Koordinat } \\
\hline & & $\mathbf{X}$ & $\mathbf{Y}$ & $\mathbf{Z}$ \\
\hline 1 & $\begin{array}{c}\text { BM } 8 \\
\text { (Cor } \\
\text { Kotak) }\end{array}$ & 376733,078 & 9541066,355 & 126,848 \\
\hline 2 & $\begin{array}{l}\text { CP } 8 \\
\text { (Cor } \\
\text { PVC) }\end{array}$ & 376732,450 & 9541089,802 & 126,089 \\
\hline
\end{tabular}

- Stake Out, pada dasarnya adalah pekerjaan pemindahan gambar-gambar desain yang diketahui koordinatnya pada gambar kerja ke posisi sesungguhnya di lapangan (Sobatnu, 2018). Implementasi dari stake out dapat digunakan untuk menentukan center line, pembuatan shop drawing, rencana pembebasan lahan dan monitoring pelaksanaan pekerjaan. Untuk mengkontrol kemiringan (slope) timbunan agar sesuai dengan gambar desain maka dibutuhkan alat bantu berupa papan kayu yang dibentuk yaitu boplang (bowplank). Pekerjaan pemasangan bowplank biasanya dilakukan bersamaan atau setelah pekerjaan pengukuran lokasi dilakukan (Sasongko, 2018).

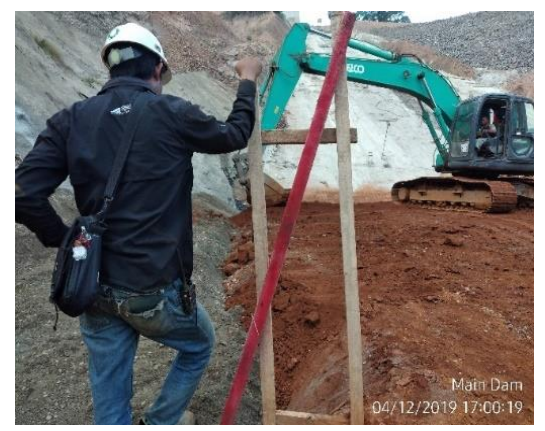

Gambar 2.5. Bowplank Pengontrol Kemiringan 
Pada stake out batas main dam, data koordinat di dapatkan dari hasil pengolahan data cross section main dam per STA sehingga dilakukan terlebih dahulu plotting pada gambar desain dan koordinat yang dihasilkan akan digunakan untuk stake out di lapangan. Untuk penentuan batas zona main dam di sesuaikan dengan ketentuan data teknis bendungan menurut Laporan Nota Desain pada Proyek Bendungan Ladongi (PT Wecon, 2016).

Tabel 2.3. Data Teknis Main Dam Bendungan Ladongi

\begin{tabular}{|c|c|}
\hline Tipe Bendungan & $\begin{array}{l}\text { Urugan batu dengan inti } \\
\text { tegak di tengah }\end{array}$ \\
\hline Panjang Puncak & $419.50 \mathrm{~m}$ \\
\hline Lebar Puncak & $10 \mathrm{~m}$ \\
\hline Elevasi Puncak & EL. $+126.00 \mathrm{~m}$ \\
\hline $\begin{array}{l}\text { Tinggi Bendungan dari } \\
\text { Galian }\end{array}$ & $66.00 \mathrm{~m}$ \\
\hline EL. Dasar Galian Pondasi & EL. $+60.00 \mathrm{~m}$ \\
\hline Kemiringan Lereng Hulu & $1: 3.00$ \\
\hline Kemiringan Lereng Hilir & $1: 2.50$ \\
\hline Lebar Zona Filter Halus & 3.00m (hulu \& hilir core) \\
\hline Lebar Zona Filter Kasar & $2.00 \mathrm{~m}$ (hulu \& hilir core) \\
\hline Lebar Dasar Core & $44.00 \mathrm{~m}$ \\
\hline
\end{tabular}

Untuk mengetahui batas-batas tersebut maka setelah plotting harus dibuatkan tanda berupa patok (marking) pada setiap batas-batas zona main dam. Lalu dilanjutkan dengan pekerjaan penimbunan, pada setiap patok yang ada dilapangan dilengkapi dengan tanda batas-batas ketebalan penghamparan di lapangan.

- Pengukuran situasi, bertujuan untuk mendapatkan gambaran situasi dari dari suatu wilayah/lokasi ke atas bidang datar dengan skala tertentu dengan menggambarkan adanya jalan, rumah, sungai, jembatan serta keadaan relief untuk berbagai keperluan teknis (Kustarto \& Hartanto, 2012). Dalam pengukuran situasi main dam di Bendungan Ladongi, dilakukan opnam atau kegiatan pengambilan data topografi pada timbunan material di lapangan termasuk batas setiap zona main dam. Hal ini dilakukan untuk mengecek elevasi timbunan diilapangan dan untuk mengambil data situasinya. Opnam dilaksanakan dalam waktu yang bervariatif yang selanjutnya data hasil pengukurannya akan diolah menjadi profil melintang (cross section).

\subsection{Cross Section}

Profil melintang atau yang biasa disebut cross section adalah penampang pada arah lebar yang menggambarkan turun naiknya permukaan suatu bentuk objek (Purwaamijaya, 2008). Data hasil pengukuran situasi di lapangan akan di input pada shop drawing yang sudah dilengkapi dengan batas-batas zona main dam. Data ini akan diolah menjadi cross section menggunakan aplikasi AutoCad Civil 3D 2017. Selanjutnya dipindahkan ke cross section gambar desain sebagai dimensi timbunan di lapangan.

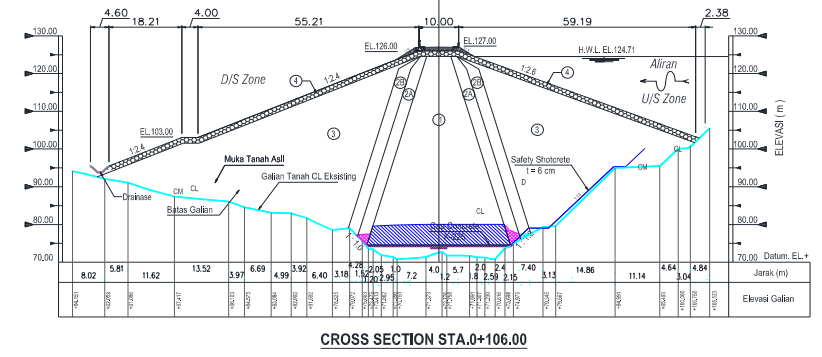

Gambar 2.6. Contoh Cross Section Hasil Pengukuran Situasi

\subsection{Cut and Fill}

Galian dan timbunan dapat diperoleh dari peta situasi yang dilengkapi dengan garis - garis kontur atau diperoleh langsung dari lapangan melalui pengukuran sipat datar profil melintang sepanjang koridor jalur proyek atau bangunan (Purwaamijaya, 2008). Terdapat beberapa metode yang biasa digunakan dalam perhitungan volume tanah salah satunya yaitu Metode Average End Area. Dengan teknik perhitungan volume dari hasil perkalian dari jarak terhadap luasan yang sudah dirata-ratakan luasannya (Lama, dkk., 2019).

$$
V=\left(\frac{A 1+A 2}{2}\right) L
$$

Dimana:

$$
\begin{aligned}
& V=\operatorname{Volume} \text { Tanah }\left(\mathrm{m}^{3}\right) \\
& \mathrm{A}=\operatorname{Luas} \text { hasil potongan }\left(\mathrm{m}^{2}\right) \\
& \mathrm{L}=\operatorname{Jarak} \text { Interval }(\mathrm{m}) .
\end{aligned}
$$

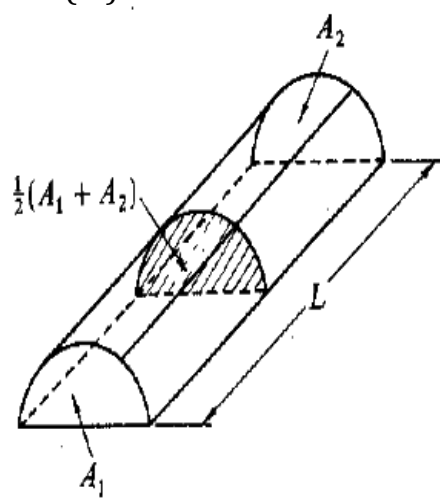

Gambar 2.7. Volume Metode Average End Area

Untuk merepresentasikan statistik bentuk topografi yang kontinyu dari koordinat yang diketahui maka data tersebut bisa direpresentasikan dengan beberapa metode salah satunya adalah Grid-Based Modeling dimana permukaan model digital terbentuk dari grid yang menghubungkan titik-titik DTM (Lama, dkk., 2019).
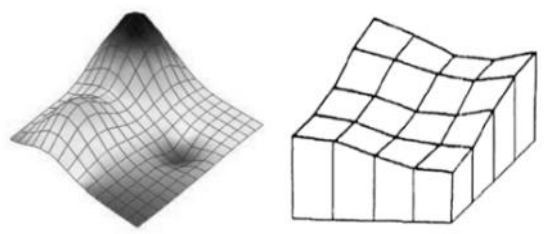

Gambar 2.8. Grid-Based Modelling 


\section{Hasil dan Pembahasan}

Pada penelitian ini hasil dan pembahasan merupakan hasil pengolahan data dari data opnam 5 sampai dengan opnam 9 yang disajikan dalam Peta Topografi serta cross section dan cut and fill timbunan main dam.

\subsection{Peta Topografi}

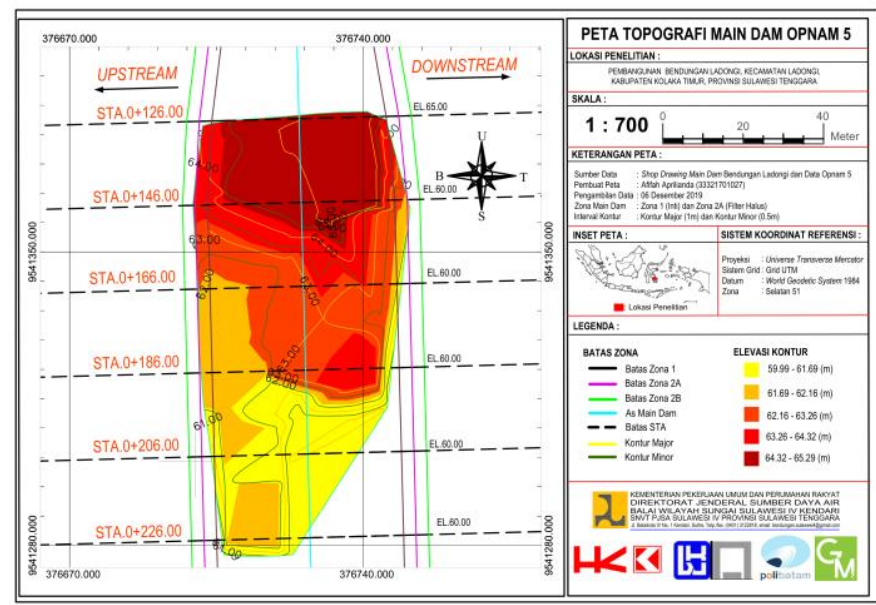

Gambar 3.1. Peta Topografi Main Dam Opnam 5

Peta Topografi Main Dam Opnam 5 terdiri dari timbunan zona 1, zona $2 \mathrm{~A}$ upstream dan zona $2 \mathrm{~A}$ downstream. Pengambilan data opnam 5 dilakukan pada 08 Desember 2019 dimana timbunan berada pada STA $0+126$ sampai dengan STA $0+226$. Elevasi tertinggi dari timbunan opnam 5 yaitu EL.+65.29 meter dengan selisih 5.29 meter dari elevasi terendahnya yaitu EL.+60.00 meter.

Batas zona main dam opnam 5 berada pada EL.+60.00 $m$ dengan lebar jarak batas zona 1 dari As bendungan adalah 22.30 meter dan diikuti lebar sebesar 3.00 meter pada masing-masing zona $2 \mathrm{~A}$ dan $2 \mathrm{~B}$ baik di upstream maupun downstream.

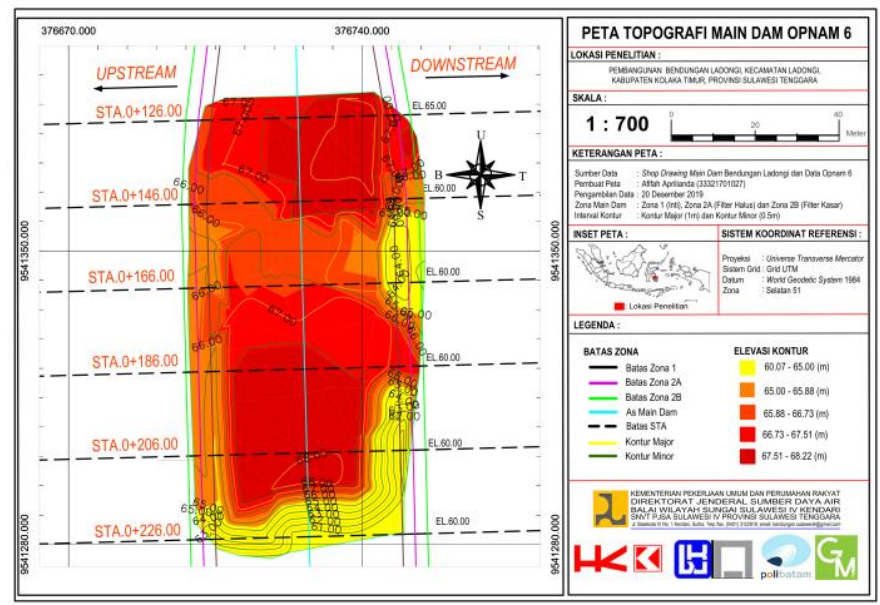

Gambar 3.2. Peta Topografi Main Dam Opnam 6

Peta Topografi Main Dam Opnam 6 berada pada STA $0+126.00$ m sampai dengan STA 0+226.00 m yang terdiri dari zona 1 , zona $2 \mathrm{~A}$ upstream, zona $2 \mathrm{~A}$ downstream, zona 2B upstream dan zona $2 \mathrm{~B}$ downstream. Pengambilan data opnam 6 dilakukan pada 20 Desember 2019 dimana elevasi tertingginya berada di EL.+68.22 meter memiliki selisih 8.15 meter dengan elevasi terendahnya yaitu EL.+60.07.

Batas zona main dam opnam 6 berada pada EL. +60.00 $m$ dengan lebar jarak batas zona 1 dari As bendungan adalah 22.30 meter dan diikuti lebar sebesar 3.00 meter pada masing-masing zona $2 \mathrm{~A}$ dan $2 \mathrm{~B}$ baik di upstream maupun downstream.

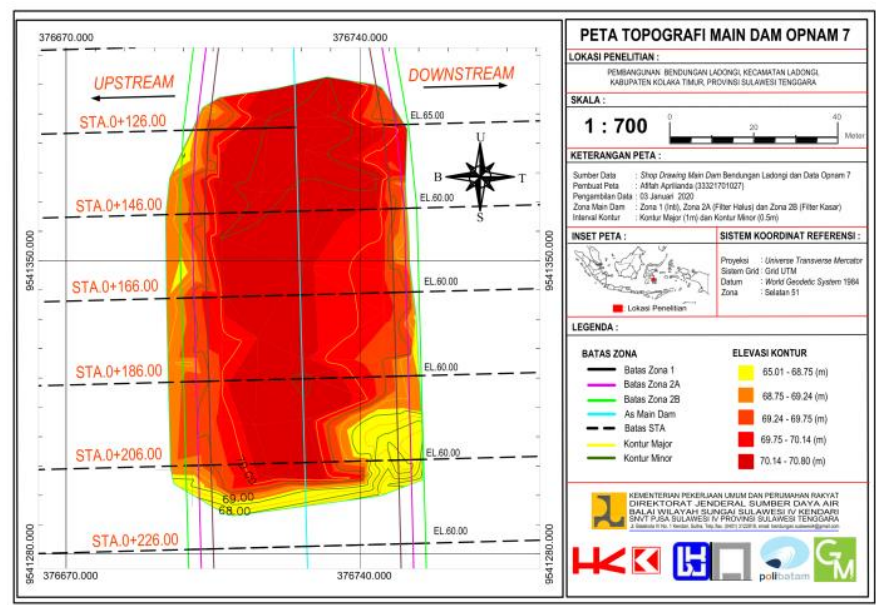

Gambar 3.3. Peta Topografi Main Dam Opnam 7

Peta Topografi Main Dam Opnam 7 berada pada STA 0+126.00 m sampai dengan STA 0+206.00 m yang terdiri dari zona 1 , zona $2 \mathrm{~A}$ upstream, zona $2 \mathrm{~A}$ downstream, zona 2B upstream dan zona 2B downstream. Pengambilan data opnam 7 dilakukan pada 03 Januari 2020 dimana elevasi tertingginya berada di EL.+70.80 meter memiliki selisih 5.79 meter dengan elevasi terendahnya yaitu EL.+65.01 m.

Batas zona main dam opnam 7 berada pada EL. +60.00 $m$ dan EL. $+65.00 \mathrm{~m}$ dengan lebar jarak batas zona 1 dari As bendungan adalah 22.30 meter dan 20.798 meter. Sedangkan pada masing-masing zona $2 \mathrm{~A}$ dan 2B baik di upstream maupun downstream memiliki lebar zona 3.00 meter.

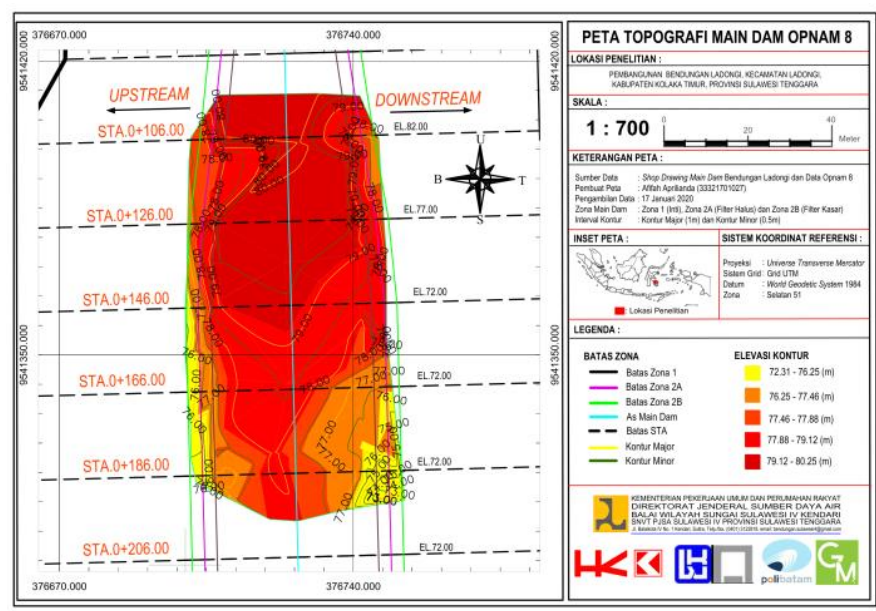

Gambar 3.4. Peta Topografi Main Dam Opnam 8

Peta Topografi Main Dam Opnam 8 berada pada STA 0+106.00 m sampai dengan STA 0+186.00 $\mathrm{m}$ yang terdiri 
dari zona 1, zona 2A upstream, zona 2A downstream, zona 2B upstream dan zona 2B downstream. Pengambilan data opnam 8 dilakukan pada 17 Januari 2020 dimana elevasi tertingginya berada di EL.+80.25 meter memiliki selisih 7.94 meter dengan elevasi terendahnya yaitu EL.+72.31 meter.

Batas zona main dam opnam 8 berada pada EL. +72.00 $\mathrm{m}$, EL.+77.00 m dan EL.+82.00 m. Sehingga lebar batas zona 1 dari As bendungan juga berbeda-beda yaitu 19.19 meter, 19.19 meter dan 14.70 meter. Sedangkan pada masing-masing zona 2A dan 2B baik di upstream maupun downstream memiliki lebar zona 3.00 meter.

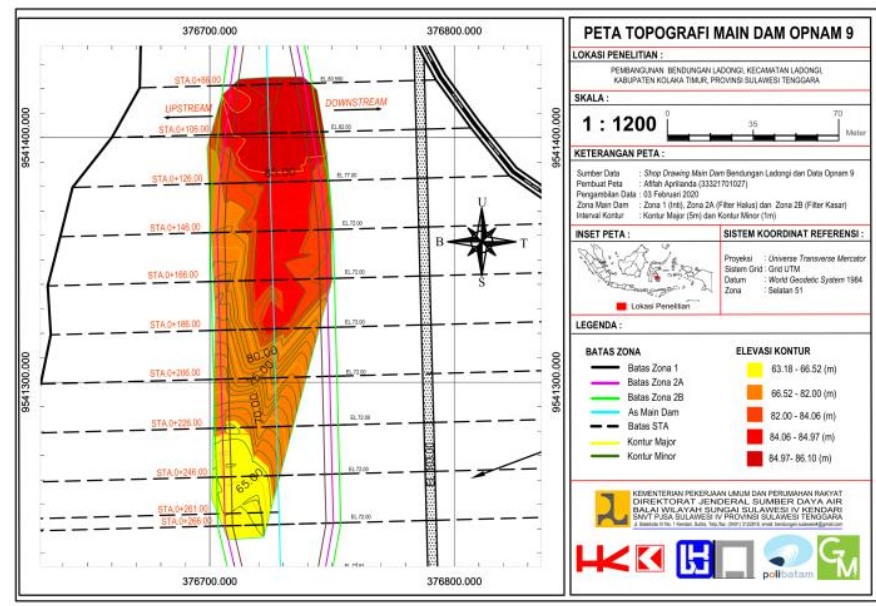

Gambar 3.5. Peta Topografi Main Dam Opnam 9

Peta Topografi Main Dam Opnam 9 berada pada STA $0+86.00 \mathrm{~m}$ sampai dengan STA $0+266.00 \mathrm{~m}$ yang terdiri dari zona 1 , zona $2 \mathrm{~A}$ upstream, zona $2 \mathrm{~A}$ downstream, zona 2B upstream dan zona 2B downstream. Pengambilan data opnam dilakukan pada 03 Februari 2020 dimana elevasi tertingginya berada di EL.+86.10 m meter memiliki selisih $22.92 \mathrm{~m}$ dengan elevasi terendahnya yaitu EL.+63.18 m.

Batas zona main dam opnam 9 berada pada EL.+83.55 m, EL.+82.00 m, EL.+77.00 m dan EL. 72.00 m. Sehingga lebar batas zona 1 dari As bendungan juga berbeda-beda yaitu $12.164 \mathrm{~m}, 14.708 \mathrm{~m}, 17.700 \mathrm{~m}$ dan $19.202 \mathrm{~m}$. Sedangkan pada masing-masing zona $2 \mathrm{~A}$ dan $2 \mathrm{~B}$ baik di upstream maupun downstream memiliki lebar zona $3.00 \mathrm{~m}$.

\subsection{Cross Section Timbunan Main Dam}

Pada penelitian ini, cross section timbunan main dam pada opnam 5 sampai dengan opnam 9 memiliki stasiun dari STA 0+86.00 m sampai dengan STA 0+266.00 m. Jarak pada setiap STA adalah 20 meter.
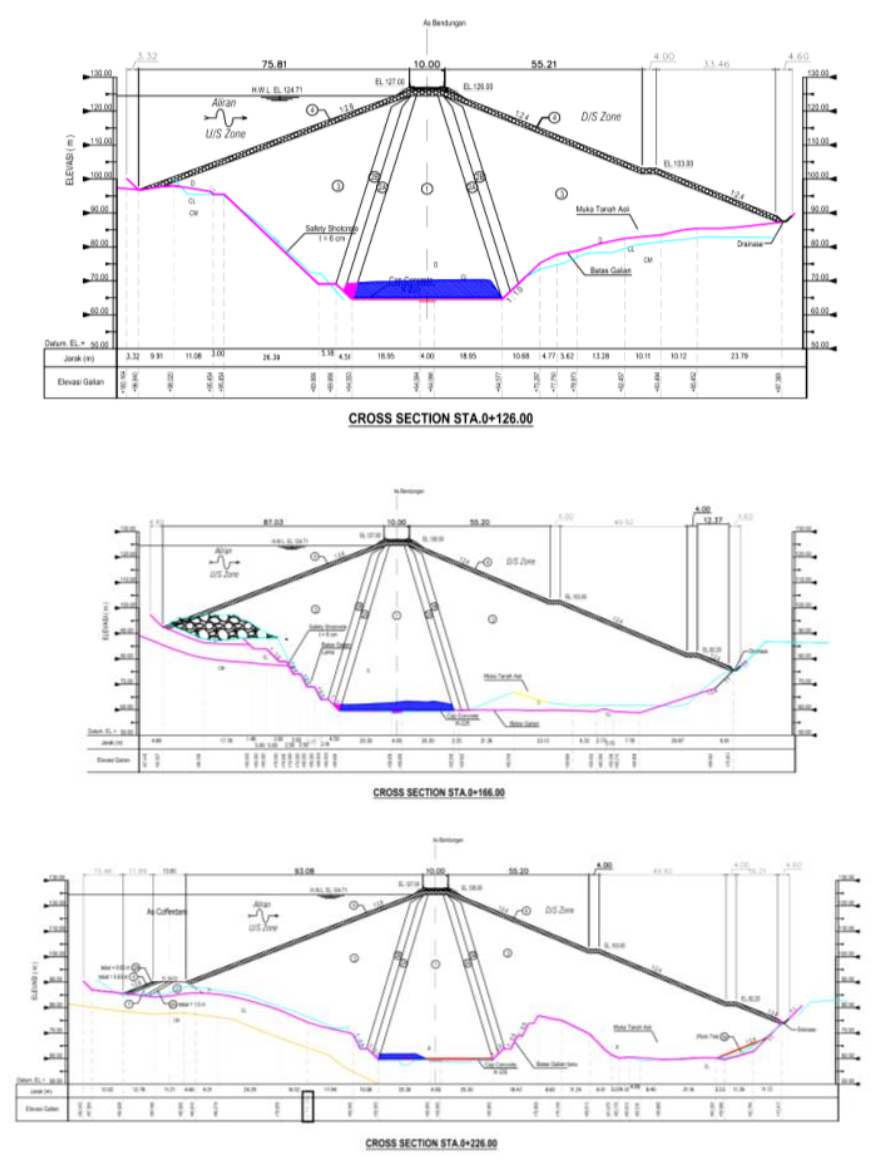

Gambar 3.6. Cross Section Main Dam Opnam 5

Pada cross section opnam 5 yang terdiri dari STA 0+126.00 sampai dengan STA $0+206.00$ memiliki luas pada setiap stasiunnya sebagai berikut.

Tabel 3.1. Data Cross Section Main Dam Opnam 5

\begin{tabular}{ccccc}
\hline Zona & Stasiun & $\begin{array}{c}\text { Jarak } \\
(\mathbf{m})\end{array}$ & $\begin{array}{c}\text { Luas } \\
\left(\mathbf{m}^{2}\right)\end{array}$ & $\begin{array}{c}\text { Luas Rata- } \\
\text { Rata }\left(\mathbf{m}^{\mathbf{2}}\right)\end{array}$ \\
\hline \multirow{2}{*}{1} & $0+126$ & & & \\
& $\begin{array}{c}\text { sampai } \\
0+206\end{array}$ & 100 & 888.769 & 777.96 \\
2A & $\begin{array}{c}0+126 \\
\text { sampai }\end{array}$ & 60 & 36.528 & 29.31 \\
Downstream & $\begin{array}{c} \\
0+186\end{array}$ & & & \\
2A & $\begin{array}{c}0+135 \\
\text { sampai } \\
\text { Upstream }\end{array}$ & 10.95 & 13.047 & 6.52 \\
\hline
\end{tabular}

Dari Tabel 3.1 diketahui luas rata-rata cross section pada setiap zona main dam berbeda-beda yaitu pada zona 1 seluas $777.96 \mathrm{~m}^{2}$, zona 2A downstream seluas $29.31 \mathrm{~m}^{2}$ dan zona 2A upstream seluas $6.52 \mathrm{~m}^{2}$. 


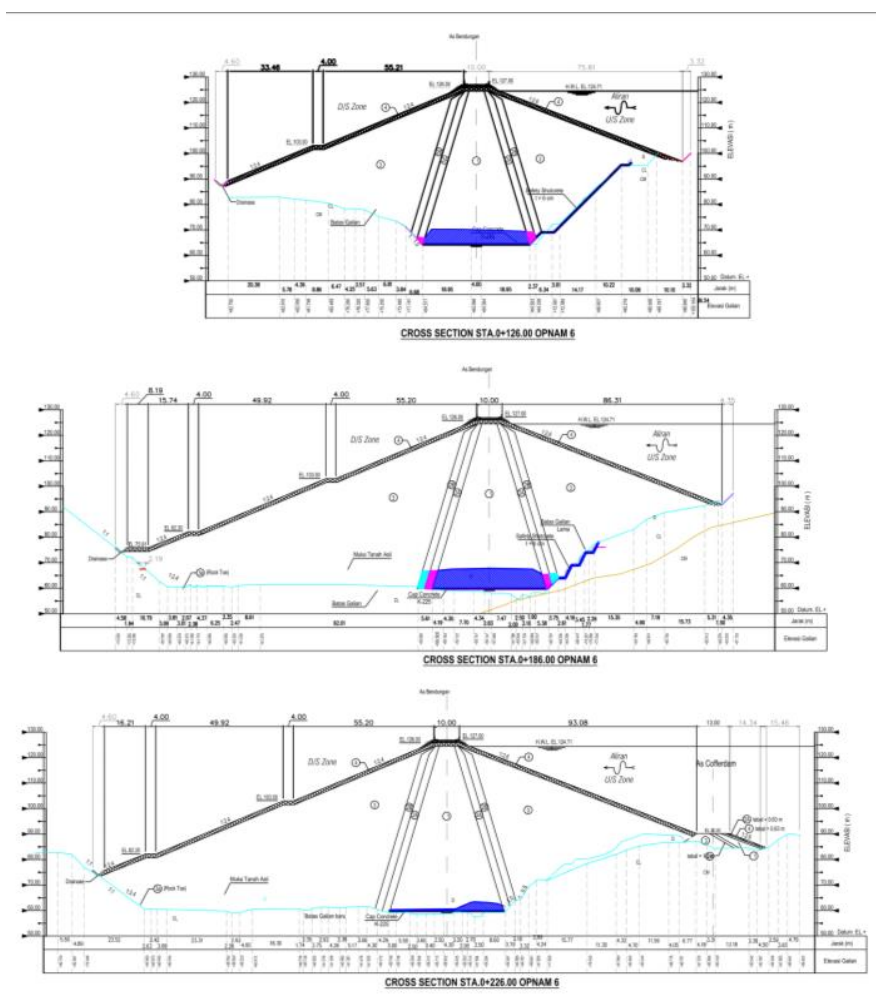

Gambar 3.7. Cross Section Main Dam Opnam 6

Pada cross section opnam 6 yang terdiri dari STA $0+126.00$ sampai dengan STA $0+226.00$ memiliki luas pada setiap stasiunnya sebagai berikut.

Tabel 3.2. Data Cross Section Main Dam Opnam 6

\begin{tabular}{|c|c|c|c|c|}
\hline Zona & Stasiun & $\begin{array}{c}\text { Jarak } \\
(\mathrm{m})\end{array}$ & $\begin{array}{l}\text { Luas } \\
\left(\mathrm{m}^{2}\right)\end{array}$ & $\begin{array}{l}\text { Luas Rata- } \\
\text { Rata }\left(\mathrm{m}^{2}\right)\end{array}$ \\
\hline 1 & $\begin{array}{c}0+126 \\
\text { sampai } \\
0+206\end{array}$ & 100 & 1465.77 & 1327.61 \\
\hline $\begin{array}{c}2 \mathrm{~A} \\
\text { Downstream }\end{array}$ & $\begin{array}{l}0+126 \\
\text { sampai } \\
0+186 \\
0+126\end{array}$ & 60 & 56.562 & 43.61 \\
\hline 2A Upstream & $\begin{array}{l}\text { sampai } \\
0+206\end{array}$ & 80 & 66.976 & 55.22 \\
\hline $\begin{array}{c}2 \mathrm{~B} \\
\text { Downstream }\end{array}$ & $\begin{array}{l}0+146 \\
\text { sampai } \\
0+186\end{array}$ & 40 & 44.082 & 29.34 \\
\hline $\begin{array}{c}\text { 2B } \\
\text { Upstream }\end{array}$ & $\begin{array}{l}0+126 \\
\text { sampai } \\
0+206\end{array}$ & 80 & 33.196 & 29.12 \\
\hline
\end{tabular}

Dari Tabel 3.2. diketahui luas rata-rata cross section pada setiap zona main dam berbeda-beda yaitu pada zona 1 seluas $1327.61 \mathrm{~m}^{2}$, zona 2A downstream seluas $43.61 \mathrm{~m}^{2}$, zona 2A upstream seluas $55.22 \mathrm{~m}^{2}$, zona $2 \mathrm{~B}$ downstream seluas $29.34 \mathrm{~m}^{2}$ dan zona $2 \mathrm{~B}$ upstream seluas $29.12 \mathrm{~m}^{2}$.

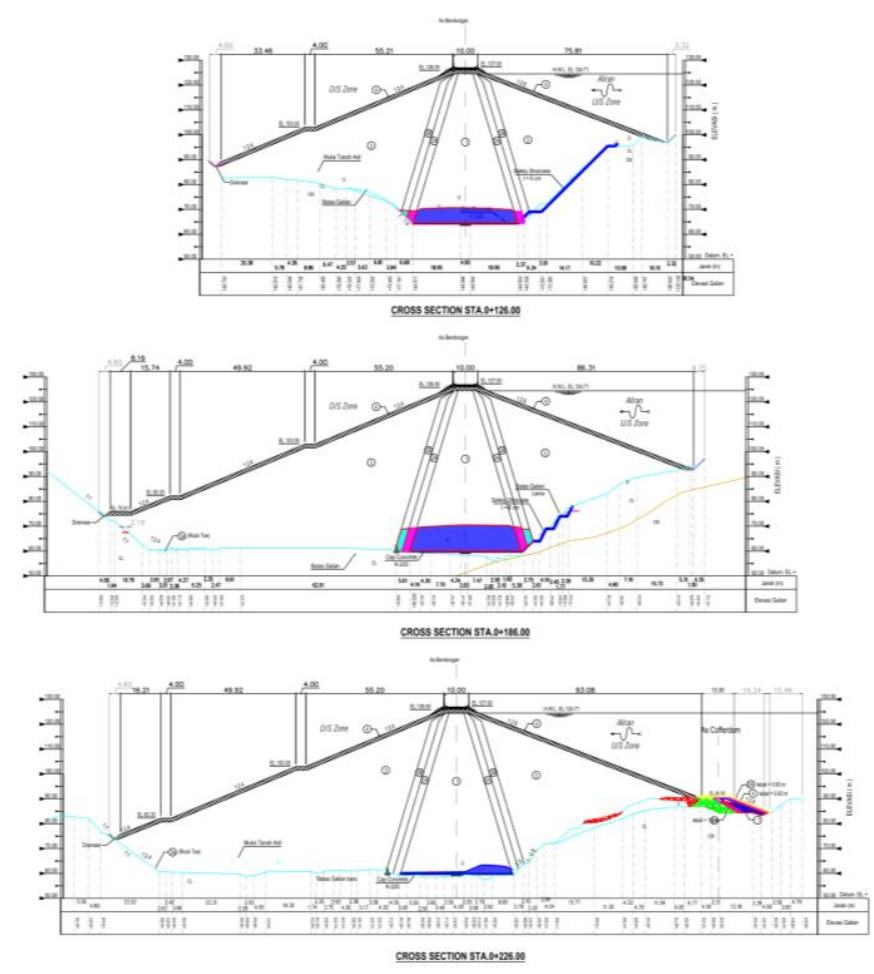

Gambar 3.8. Cross Section Main Dam Opnam 7

Pada cross section opnam 7 yang terdiri dari STA 0+126.00 sampai dengan STA 0+206.00 memiliki luas pada setiap stasiunnya sebagai berikut.

Tabel 3.3. Data Cross Section Main Dam Opnam 7

\begin{tabular}{|c|c|c|c|c|}
\hline Zona & Stasiun & $\begin{array}{c}\text { Jarak } \\
(\mathrm{m})\end{array}$ & $\begin{array}{l}\text { Luas } \\
\left(\mathrm{m}^{2}\right)\end{array}$ & $\begin{array}{c}\text { Luas } \\
\text { Rata- } \\
\text { Rata }\left(\mathbf{m}^{2}\right) \\
\end{array}$ \\
\hline 1 & $\begin{array}{c}0+126 \\
\text { sampai } \\
0+206\end{array}$ & 80 & 1912.11 & 1594.6 \\
\hline $\begin{array}{c}2 \mathrm{~A} \\
\text { Downstream }\end{array}$ & $\begin{array}{l}0+126 \\
\text { sampai } \\
0+206\end{array}$ & 80 & 123.514 & 97.17 \\
\hline 2A Upstream & $\begin{array}{l}0+126 \\
\text { sampai } \\
0+206\end{array}$ & 80 & 121.743 & 90.09 \\
\hline $\begin{array}{c}\text { 2B } \\
\text { Downstream }\end{array}$ & $\begin{array}{l}0+126 \\
\text { sampai } \\
0+206\end{array}$ & 80 & 99.752 & 87.85 \\
\hline $\begin{array}{c}2 \mathrm{~B} \\
\text { Upstream }\end{array}$ & $\begin{array}{l}0+146 \\
\text { sampai } \\
0+206\end{array}$ & 60 & 69.304 & 51.87 \\
\hline
\end{tabular}

Dari Tabel 3.3. diketahui luas rata-rata cross section pada setiap zona main dam berbeda-beda yaitu pada zona 1 seluas $1594.6 \mathrm{~m}^{2}$, zona 2A downstream seluas $97.17 \mathrm{~m}^{2}$, zona 2A upstream seluas $90.09 \mathrm{~m}^{2}$, zona 2B downstream seluas $87.85 \mathrm{~m}^{2}$ dan zona $2 \mathrm{~B}$ upstream seluas $51.87 \mathrm{~m}^{2}$. 


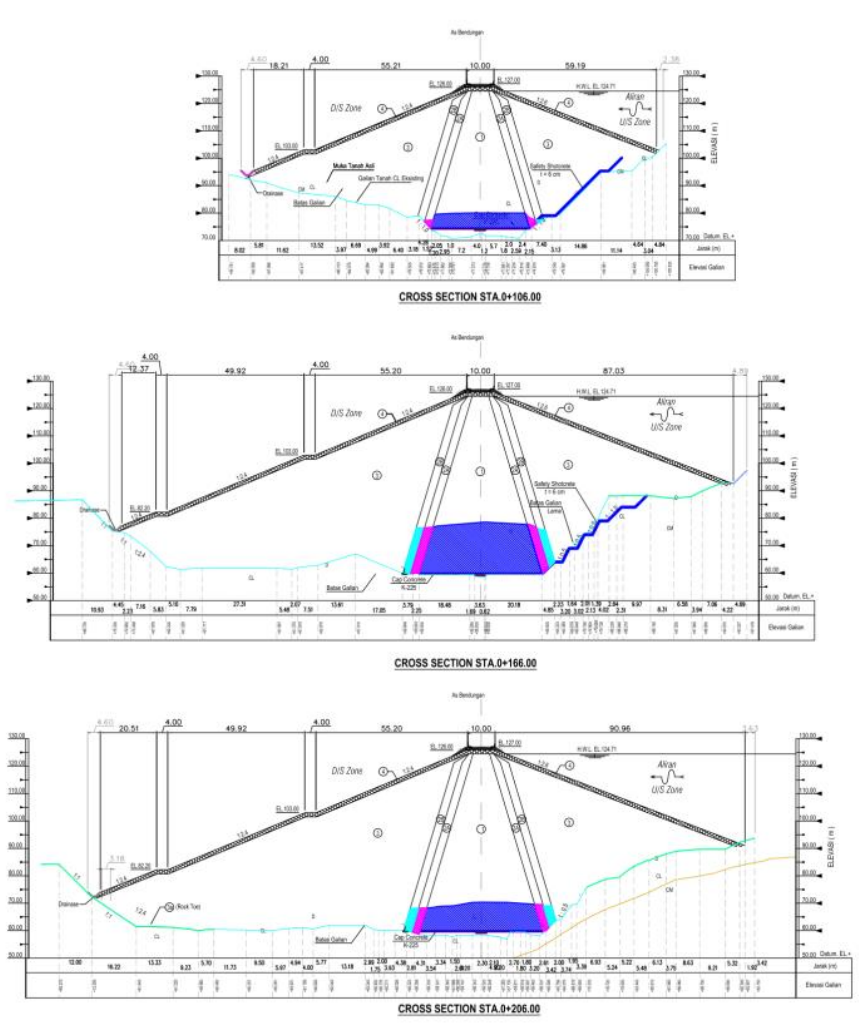

Gambar 3.9. Cross Section Main Dam Opnam 8

Pada cross section opnam 8 yang terdiri dari STA $0+106.00$ sampai dengan STA $0+186.00$ memiliki luas pada setiap stasiunnya sebagai berikut.

Tabel 3.4. Data Cross Section Main Dam Opnam 8

\begin{tabular}{ccccc}
\hline Zona & Stasiun & $\begin{array}{c}\text { Jarak } \\
(\mathbf{m})\end{array}$ & $\begin{array}{c}\text { Luas } \\
\mathbf{( m}^{2} \mathbf{)}\end{array}$ & $\begin{array}{c}\text { Luas Rata- } \\
\text { Rata }\left(\mathbf{m}^{2} \mathbf{)}\right.\end{array}$ \\
\hline \multirow{4}{*}{$\begin{array}{c}0+106 \\
\text { sampai } \\
0+186\end{array}$} & 80 & 688.60 & 2445.97 \\
& $0+106$ & & & \\
2A & sampai & 80 & 193.87 & 168.24 \\
Downstream & $0+186$ & & & \\
& $0+106$ & & & \\
2A Upstream & $\begin{array}{c}\text { sampai } \\
0+186\end{array}$ & 80 & 203.346 & 174.72 \\
& $0+126$ & & & \\
2B & sampai & 60 & 168.379 & 131.6 \\
Downstream & $0+186$ & & & \\
& $0+126$ & & & \\
2B & sampai & 60 & 152.686 & 116.61 \\
Upstream & $0+186$ & & & \\
\hline
\end{tabular}

Dari Tabel 3.4. diketahui luas rata-rata cross section pada setiap zona main dam berbeda-beda yaitu pada zona 1 seluas $2445.97 \mathrm{~m}^{2}$, zona 2A downstream seluas 168.24 $\mathrm{m}^{2}$, zona 2A upstream seluas $174.72 \mathrm{~m}^{2}$, zona 2B downstream seluas $131.6 \mathrm{~m}^{2}$ dan zona $2 \mathrm{~B}$ upstream seluas $116.61 \mathrm{~m}^{2}$

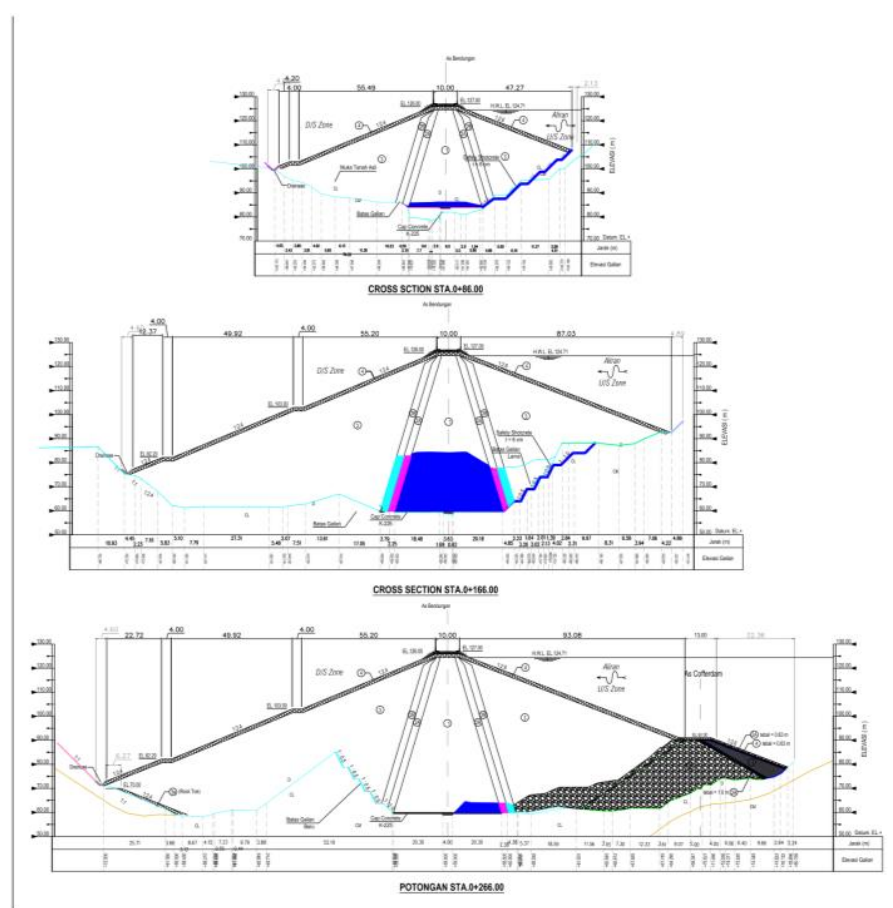

Gambar 3.10. Cross Section Main Dam Opnam 9

Pada cross section opnam 9 yang terdiri dari STA 0+86.00 sampai dengan STA 0+266.00 m memiliki luas pada setiap stasiunnya sebagai berikut.

Tabel 3.5. Data Cross Section Main Dam Opnam 9

\begin{tabular}{|c|c|c|c|c|}
\hline Zona & Stasiun & $\begin{array}{c}\text { Jarak } \\
(\mathrm{m})\end{array}$ & $\begin{array}{l}\text { Luas } \\
\left(\mathrm{m}^{2}\right)\end{array}$ & $\begin{array}{l}\text { Luas Rata- } \\
\text { Rata }\left(\mathrm{m}^{2}\right)\end{array}$ \\
\hline 1 & $\begin{array}{c}0+86 \\
\text { sampai } \\
0+266\end{array}$ & 80 & 4627.19 & 39415.8 \\
\hline $\begin{array}{c}2 \mathrm{~A} \\
\text { Downstream }\end{array}$ & $\begin{array}{c}0+106 \\
\text { sampai } \\
0+206 \\
0+106\end{array}$ & 80 & 295.175 & 267.41 \\
\hline 2A Upstream & $\begin{array}{c}\text { sampai } \\
0+266\end{array}$ & 80 & 314.611 & 295.75 \\
\hline $\begin{array}{c}\text { 2B } \\
\text { Downstream }\end{array}$ & $\begin{array}{c}0+106 \\
\text { sampai } \\
0+206\end{array}$ & 60 & 264.047 & 241.77 \\
\hline $\begin{array}{c}2 \mathrm{~B} \\
\text { Upstream }\end{array}$ & $\begin{array}{c}0+106 \\
\text { sampai } \\
0+266\end{array}$ & 60 & 263.638 & 247.98 \\
\hline
\end{tabular}

Dari Tabel 3.5. diketahui luas rata-rata cross section pada setiap zona main dam berbeda-beda yaitu pada zona 1 seluas $39415.8 \mathrm{~m}^{2}$, zona $2 \mathrm{~A}$ downstream seluas 267.41 $\mathrm{m}^{2}$, zona 2A upstream seluas $295.75 \mathrm{~m}^{2}$, zona 2B downstream seluas $241.77 \mathrm{~m}^{2}$ dan zona 2B upstream seluas $247.98 \mathrm{~m}^{2}$.

\subsection{Cut and Fill Timbunan Main Dam}

Dari hasil pengolahan data opnam menjadi cross section selanjutnya dapat dihitung volume timbunan yang ada menggunakan metode average end area (mengalikan jarak STA dengan rata-rata luas cross section). Berikut tabel volume timbunan main dam. 
Tabel 3.6. Volume Timbunan Main Dam

\begin{tabular}{|c|c|c|c|c|}
\hline No & Nama & $\begin{array}{l}\text { Zona Main } \\
\text { Dam }\end{array}$ & $\begin{array}{c}\text { Quantity } \\
\left(\mathrm{m}^{3}\right)\end{array}$ & Jumlah \\
\hline \multirow{3}{*}{1} & Opnam & 1 & 11,498 & \multirow{3}{*}{11,965} \\
\hline & \multirow{2}{*}{$\begin{array}{l}5 \\
(06 \text { Des } \\
19)\end{array}$} & 2A Downstream & 395 & \\
\hline & & 2A Upstream & 72 & \\
\hline \multirow{5}{*}{2} & \multirow{5}{*}{$\begin{array}{l}\text { Opnam } \\
6 \\
(20 \text { Des } \\
19)\end{array}$} & 1 & 26,553 & \multirow{5}{*}{29,701} \\
\hline & & 2A Downstream & 873 & \\
\hline & & 2A Upstream & 1,105 & \\
\hline & & 2B Downstream & 587 & \\
\hline & & 2B Upstream & 583 & \\
\hline \multirow{5}{*}{3} & \multirow{5}{*}{$\begin{array}{l}\text { Opnam } \\
7 \\
(03 \text { Jan } \\
20)\end{array}$} & 1 & 36,516 & \multirow{5}{*}{43,057} \\
\hline & & 2A Downstream & 1,944 & \\
\hline & & 2A Upstream & 1,802 & \\
\hline & & 2B Downstream & 1,757 & \\
\hline & & 2B Upstream & 1,038 & \\
\hline \multirow{5}{*}{4} & \multirow{5}{*}{$\begin{array}{l}\text { Opnam } \\
8 \\
(17 \text { Jan } \\
20)\end{array}$} & 1 & 64,561 & \multirow{5}{*}{79,107} \\
\hline & & 2A Downstream & 4,097 & \\
\hline & & 2A Upstream & 4,247 & \\
\hline & & 2B Downstream & 3,300 & \\
\hline & & 2B Upstream & 2,902 & \\
\hline \multirow{6}{*}{5} & \multirow{5}{*}{$\begin{array}{l}\text { Opnam } \\
9 \\
(03 \mathrm{Feb} \\
20)\end{array}$} & 1 & 78,318 & \multirow{5}{*}{99,378} \\
\hline & & 2A Downstream & 5,349 & \\
\hline & & 2A Upstream & 5,915 & \\
\hline & & 2B Downstream & 4,836 & \\
\hline & & 2B Upstream & 4,960 & \\
\hline & & & Total Volume & 263,208 \\
\hline
\end{tabular}

Dari Tabel 3.6. dapat diketahui volume total pada opnam 5 sebesar 11,965 $\mathrm{m}^{3}$, volume opnam 6 sebesar $29,701 \mathrm{~m}^{3}$, volume opnam 7 sebesar $43,057 \mathrm{~m}^{3}$, volume opnam 8 sebesar 79,107 $\mathrm{m}^{3}$, dan volume opna 9 sebesar $99,378 \mathrm{~m}^{3}$.

Selain dapat diketahui volume timbunan, data pengukuran situasi main dam dapat divisualisasikan dalam bentuk tiga dimensi menggunakan software Surfer 9. Dengan menggunakan metode grid-based modeling dimana permukaan model digital dibentuk dari grid yang menghubungkan titik-titik DTM. Berikut merupakan representasi dari data situasi opnam 5 sampai dengan opnam 9.

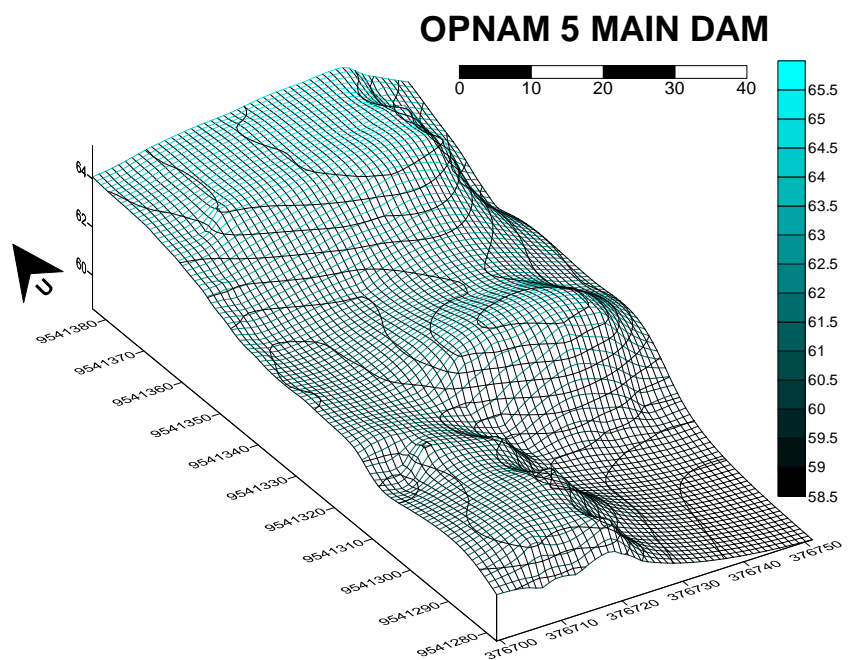

Gambar 3.11. Visualisasi Grid-Modelling Opnam 5

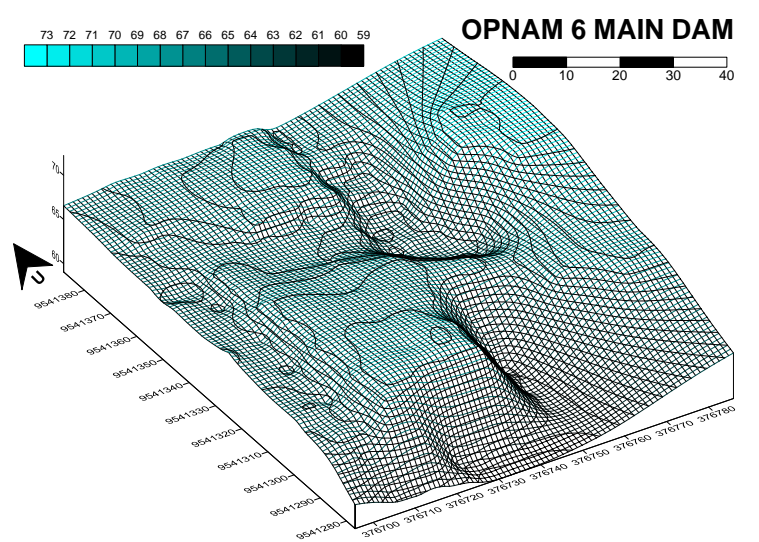

Gambar 3.12. Visualisasi Grid-Modelling Opnam 6

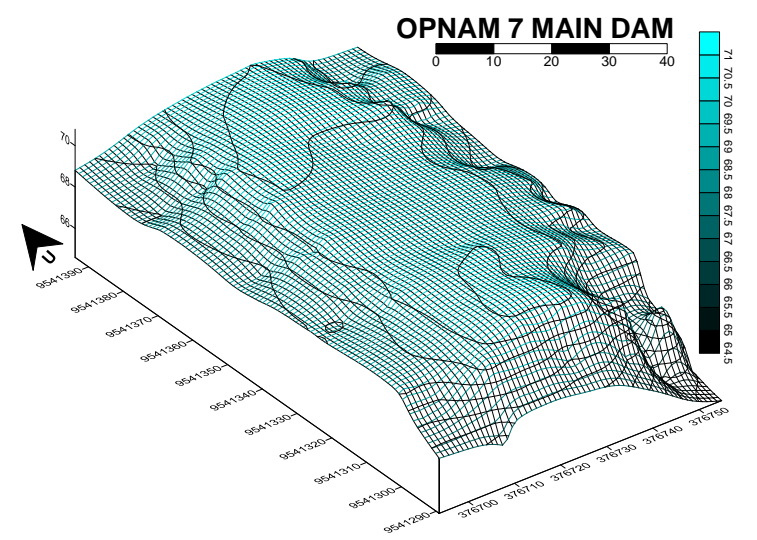

Gambar 3.13. Visualisasi Grid-Modelling Opnam 7

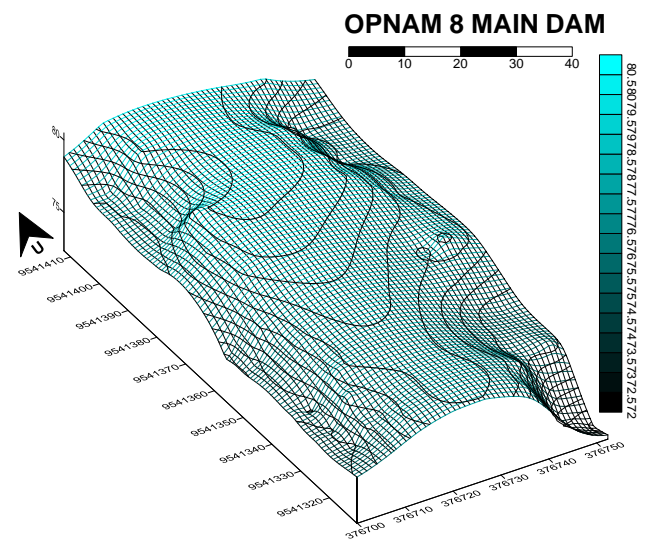

Gambar 3.14. Visualisasi Grid-Modelling Opnam 8

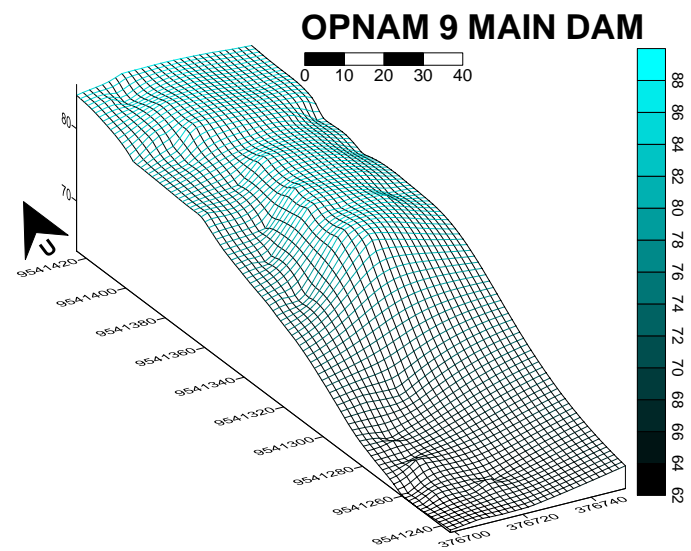

Gambar 3.15. Visualisasi Grid-Modelling Opnam 


\section{Kesimpulan}

Survey berperan penting pada pelaksanaan penentuan dan pengontrolan batas zona penyusun main dam yang bertujuan agar penimbunan material bendungan sesuai dengan gambar kerja dan bendungan dapat berfungsi sebagaimana mestinya. Pada penentuan batas zona penyusun main dam dilakukan sesuai data teknis bendungan yang selanjutnya dilakukan pelaksanaan di lapangan. Untuk mengontrol batas zona penyusun main dam dilakukan dengan menggunakan metode stake out dari koordinat batas main dam dan menggunakan alat bantu berupa bowplank untuk mengontrol kemiringan timbunan (slope). Hasil pengukuran situasi main dam diolah menjadi Peta Topografi, cross section timbunan dan dapat divisualisasikan menjadi tiga dimensi. Pada Peta Topografi Opnam 5 memiliki variasi elevasi $+60.00 \mathrm{~m}$ sampai dengan elevasi $+65.29 \mathrm{~m}$ dan volume timbunannya sebesar 11,965 $\mathrm{m}^{3}$. Pada Peta Topografi Opnam 6 memiliki variasi elevasi $+60.07 \mathrm{~m}$ sampai elevasi $+68.22 \mathrm{~m}$ dan volume timbunannya sebesar $29,701 \mathrm{~m}^{3}$. Peta Topografi Opnam 7 memiliki elevasi terendah $+65.01 \mathrm{~m}$ sampai elevasi tertinggi $+70.80 \mathrm{~m}$ dan volume timbunannya sebesar 43,057 $\mathrm{m}^{3}$. Pada Peta Topografi Opnam 8 memiliki variasi elevasi $+72.31 \mathrm{~m}$ sampai dengan elevasi $+80.25 \mathrm{~m}$ dan volume timbunannya sebesar $79,107 \mathrm{~m}^{3}$. Dan Peta Topografi Opnam 9 memiliki elevasi terendah $+63.18 \mathrm{~m}$ sampai dengan elevasi $+86.10 \mathrm{~m}$ dan volume timbunannya sebesar $99,378 \mathrm{~m}^{3}$.

\section{Pernyataan Konflik Kepentingan}

Penulis menyatakan tidak ada konflik kepentingan dalam artikel ini (The authors declare no competing interest).

\section{Referensi}

Adi, W. T., \& Aghastya, A. (2017). Penggunaan Total Station dan AutoCAD Civil 3D Untuk Perencanaan Grading. Jurnal Perkeretaapian Indonesia, 1(2), hal 149-159.

Asiyanto. (2011). Metode Konstruksi Bendungan. Jakarta: Penerbit Universitas Indonesia (UI-Press).

Balai Keamanan Bendungan, Direktorat Bina Teknik, \& Ditjen Sumber Daya Air. (2003). Pedoman Kriteria Umum Desain Bendungan. Jakarta: Balai Keamanan Bendungan.

Dharmayasa, I. N., Redana, I., \& Putra, T. G. (2014). Analisis keamanan lereng Bendungan Utama pada Bendungan Benel di Kabupaten Jembrana. Jurnal Spektran.

Kustarto, H., \& Hartanto, A. (2012). Ilmu Ukur Tanah Metode dan Aplikasi Bagian Kedua (Cetakan Pertama ed.). Malang: PENERBIT DIOMA.

Lama, A. R., Sai, S. S., \& Mabrur, A. Y. (2019). Analisis Ketelitian Perhitungan Volume Galian
Menggunakan Data Gridding dan Tanpa Gridding Pada Pekerjaan Bendungan (Studi Kasus: Bendungan Rotiklot, Kabupaten Belu - NTT).

Nasmiarta, Z. M., Hendrawan, A. P., \& Saputra, A. W. (2016). Analisa Stabilitas Tubuh Bendungan Pada Perencanaan Bendungan Ladongi Kabupaten Kolaka Timur Sulawesi Tengara.

Peraturan Pemerintah Republik Indonesia Nomor 37 Tahun 2010 Bendungan. 18 Februari 2010. Lembaran Negara Republik Indonesia Tahun 2010 Nomor 45. Jakarta.

Peraturan Presiden Republik Indonesia Nomor 3 Tahun 2016 Percepatan Pelaksanaan Proyek Strategis Nasional. 8 Januari 2016. Lembaran Negara Republik Indonesia Tahun 2016 Nomor 4. Jakarta.

Pemerintah Indonesia. (2010). Peraturan Pemerintah Republik Indonesia Nomor 37 Tahun 2010 Pasal 1 Tentang Bendungan. Jakarta: Peraturan Pemerintah Republik Indonesia.

Proyek Bendungan Ladongi. (2019). Metode Pelaksanaan Penimbunan Tubuh Bendungan. Kolaka Timur: Hutama Karya - Bumi Karsa, KSO;.

PT Wecon. (2016). Laporan Nota Desain Proyek Pembangunan Bendungan Ladongi. Kolaka Timur: Kementrian Pekerjaan Umum dan Perumahan Rakyat.

Purwaamijaya, I. M. (2008). Teknik Survey dan Pemetaan Jilid 3. Jakarta: Departemen Pendidikan Nasional.

Pusat Pembinaan Kompetensi \& Pelatihan Konstruksi. (2011). Materi Pelatihan Berbasis Kompetensi Sektor Konstruksi Sub Sektor Bangunan Gedung. In Juru Ukur Bangunan Gedung (Stake Out dan Monitoring) (hal 16-167). Jakarta Selatan: Kementerian Pekerjaan Umum Badan Pembinaan Konstruksi.

Republik Indonesia. (2016). Peraturan Presiden Republik Indonesia Nomor 3 Tahun Tentang Percepatan Pelaksanaan Proyek Strategis Nasional. Jakarta.

Sasongko, R. (2018). Survey Rekayasa Konstruksi (Cetakan Pertama). Malang: POLINEMA PRESS.

Sobatnu, F. (2018). Survei Terrestris (Cetakan Pertama). Banjarmasin: POLIBAN PRESS.

Soedibyo. (2003). Teknik Bendungan (Cetakan Kedua). Jakarta: PT Pradnya Paramita.

Susetyo, D. B., Yuniar, H. T., \& Saputra, L. R. (2013). Standarisasi Aplikasi Survey Pemetaan Terestris Dalam Bidang Konstruksi Struktur Bawah Bangunan. Forum Ilmiah Tahunan Ikatan Surveyor Indonesia.

Suyono, S., \& Takeda, K. (1977). Bendungan Type Urugan (Cetakan Kedua). Jakarta: PT. PRADNYA PARAMI. 